\title{
Flat Belt Separation System under Slat in Fattening Pig Housing: Effect of Belt Slope Angle
}

\section{Francisco Alonso*, Aranzazu Mateos, Jesús Vázquez, Miguel Angel Garcimartín, Elvira Sánchez, Ismael Ovejero}

Escuela Técnica Superior de Ingeniería Agronómica Alimentaria y de Biosistemas, Technical University of Madrid, Ciudad Universitaria, Madrid, Spain

Email: * paco.alonso.peralta@upm.es

How to cite this paper: Alonso, $F$. Mateos, A., Vázquez, J., Garcimartín, M.A., Sánchez, E. and Ovejero, I. (2018) Flat Belt Separation System under Slat in Fattening Pig Housing: Effect of Belt Slope Angle. Agricultural Sciences, 9, 692-702.

https://doi.org/10.4236/as.2018.96048

Received: April 20, 2018

Accepted: June 22, 2018

Published: June 25, 2018

Copyright (๑) 2018 by authors and Scientific Research Publishing Inc. This work is licensed under the Creative Commons Attribution International License (CC BY 4.0).

http://creativecommons.org/licenses/by/4.0/

\begin{abstract}
In this study, the separation and drying efficiency of the excreta, separated into solid and liquid fraction by a flat conveyor belt under a partial slatted floor in a facility for fattening pigs, was determined. Two transverse slope angles $\left(4^{\circ}\right.$ and $\left.6^{\circ}\right)$ for the flat belts were used, in a trial with pigs from 20.61 to $117.83 \mathrm{~kg}$ of live weight (LW), and the sample size was 7 pigs per pen, 42 pigs per room. The flat belt was more efficient with $6^{\circ}$ than with $4^{\circ}$ slope angle (32.65\% vs. $29.91 \%$ dry matter content of solid fraction during the whole fattening period, respectively; $P<0.0001$ ). The separation and drying efficiency of the excreta, defined as the ratio of dry matter content of the solid fraction to dry matter content of fresh faeces, were significantly higher for the angle of $6^{\circ}$ than for the $4^{\circ}$ (1.4137 vs. 1.3030 , during the whole fattening period; $P<$ $0.0001)$. With a slope angle of $6^{\circ}$, this efficiency was not improved in finishing period -83.40 to $117.83 \mathrm{~kg} \mathrm{LW}$ (two extractions per day) with regard to the growth period -20.61 to $83.40 \mathrm{~kg} \mathrm{LW}$ (one extraction per day). Meanwhile, with $4^{\circ}$ it did improved. The ventilation system underneath slat seems to play a key role in the obtained results.
\end{abstract}

\section{Keywords}

Flat Belt, Manure, Separation and Drying Efficiency, Separation System, Swine

\section{Introduction}

Traditionally, the pig wastes are collected in pits under the slatted floor in which are stored. An improvement to this method was the replacement of the pit by 
canals also under the partial slatted floor. These canals collect and run off the slurry to a pit outside the livestock. The slurry collected by both systems has low dry matter content and produces large volumes of waste. These systems increase the management cost of the waste. Otherwise, the European Union Directive 91/676/CEE limits the permissible dose of nitrogen for agricultural soil to 170 $\mathrm{kg} / \mathrm{ha}$. This means that for every 100 fattening pig places, a surface area of 4.5 6.0 ha of land is necessary to disperse slurry without risk of contaminating soil and water tables.

Pig slurry over-application carries the risk of environmental pollution [1]. The contamination is the result of an excessive spreading of nitrogen and phosphorus to soil. Nitrogen in slurry mainly comes from urine, and phosphorus from faeces [2].

Several research groups [2] [3] [4] [5] [6] have proposed the separation of urine and faeces through the use of a belt below slatted floor. These systems reduce the residence time of the waste under the slatted floor and they decrease the ammonia emissions and odors. Also, they improve animal welfare, reduce the volume of generated residues and make easier farm management.

Our previous studies [7] [8] have shown that the separation system proposed by [4] separates faeces and urine properly. The studies of [8] also showed that the flat belt was more effective than the concave belt for the separation, and the flat belt was more efficient in dry matter content of the solid fraction with greater transverse slope angle.

The aim of this study was to determine the influence of slope angle of the flat belt system proposed by [4] on amounts produced and characteristic of residues in a fattening facility with exhaust mechanical ventilation underneath animal locations.

\section{Materials and Methods}

\subsection{Facilities}

The experiment was carried out at 2014 in the Pig Welfare Laboratory (Universidad Politécnica de Madrid) (Figure 1). This is a facility for fattening pigs with four independent rooms with six boxes per room. The dimensions of the box are $3.10 \mathrm{~m}$ long $\times 2.30 \mathrm{~m}$ wide; $60 \%$ concrete continuous floor and the rest with slat.

In this experiment we only have used two (A, B) of the four rooms of the building. In rooms $A$ and $B$, the manure separation system with a flat belt under slats was installed.

The two rooms have a mechanical exhaust ventilation system with the fans located under the space occupied by the animals; as such the ventilating air circulates over the flat belt [9]. The flow ventilation rates were regulated according to the desired temperature (from $24^{\circ} \mathrm{C}-26^{\circ} \mathrm{C}$ at the beginning to $20^{\circ} \mathrm{C}-24^{\circ} \mathrm{C}$ at the end of the trial), and since the animal live weights per room were similar (initial coefficient of variation, 13.33\%; final coefficient of variation, 9.97\%) the flows ventilation rates were similar for all rooms. 


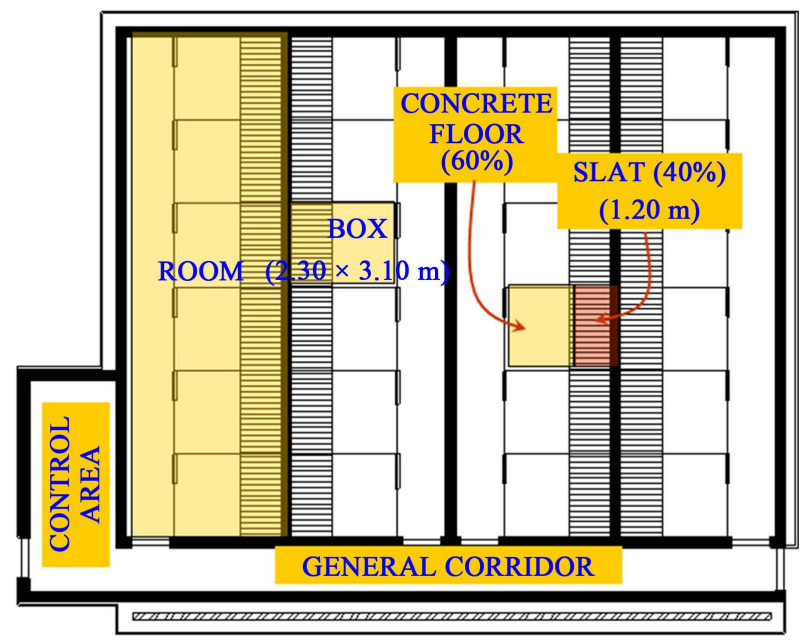

Figure 1. Plan of the pig welfare laboratory.

The flat belts were $0.60 \mathrm{~m}$ wide and could be adjusted crossways from $0^{\circ}-8^{\circ}$ ( $0 \%-14.5 \%$ slope) and on one side has a gutter to collect the liquid fraction separated (Figure 2).

\subsection{Animals}

84 pig barrows were used, ( 7 pigs per box, 42 per room): available surface per pig was $1.05 \mathrm{~m}^{2}$ (40\% slatted floor) during the whole fattening period in compliance with European Union space requirements. Live weight at the start of the fattening period was $20.61 \pm 2.75 \mathrm{~kg}$, then being fattened up to a final weight of 117.83 $\pm 11.75 \mathrm{~kg}$ and they were fed ad libitum (Table 1). The distribution of initial weight in each room was similar.

\subsection{Experimental Procedure}

The slope angles on the flat belts in rooms A and B were $4^{\circ}$ and $6^{\circ}$, respectively, during the whole fattening period. Those angles were chosen according to our previous studies [8] and let enough space between belt and deflectors to not limit flow ventilation rates.

Excreta (faeces and urine) fell onto the belts through the slats. The belts in both rooms were emptied once a day from the start of fattening period to a live weight of $83.4 \mathrm{~kg}$ - growth period, and twice a day until the end of the fattening period-finishing period (Table 2). Throughout the fattening period the boxes were dry cleaned daily.

Solid fraction and liquid fraction were stored in containers and, respectively, measured and emptied weekly and daily. Solid fraction samples were taken weekly during the fattening cycle: once the container was empty and after the belts were in operation, the solid fractions were homogenized and three samples were taken per room. Also, three fresh faeces samples per room were taken from the pens slatted floor every week. Once day per week, also three liquid fraction samples per room were taken from the liquid fraction container. 

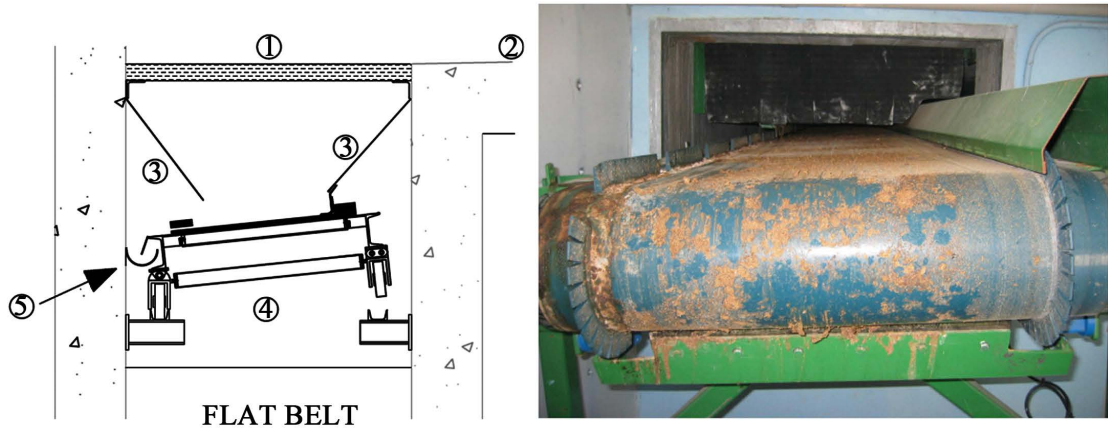

Figure 2. Transversal section and image of flat belt (1, slatted floor; 2, concrete floor; 3 , deflector; 4 , belt; 5 , gutter).

Table 1. Calculated chemical composition of the diets (\% dry matter was around 89\%).

\begin{tabular}{ccccc}
\hline \multirow{2}{*}{ Chemical composition } & \multicolumn{2}{c}{ Growth period $^{\mathrm{a}}$} & \multicolumn{2}{c}{ Finishing period $^{\mathrm{a}}$} \\
\cline { 2 - 5 } & Starter & Grower A & Grower B & Finisher \\
\hline Crude protein, \% & 17.70 & 17.40 & 16.80 & 15.50 \\
Crude fat, \% & 3.80 & 4.50 & 5.00 & 4.20 \\
Crude fiber, \% & 4.70 & 3.90 & 4.00 & 4.40 \\
Ash, \% & 6.00 & 5.30 & 5.10 & 4.50 \\
Lysine, \% & 1.07 & 0.99 & 0.90 & 0.76
\end{tabular}

${ }^{\mathrm{a}}$ Growth period: 20.61 - $83.40 \mathrm{~kg}$ live weight; finishing period: 83.40 - $117.83 \mathrm{~kg}$ live weight.

Table 2. Experimental design in the rooms.

\begin{tabular}{|c|c|c|c|c|c|}
\hline Room & Belt & Slope & Periods & Slope angle & Extractions day ${ }^{-1}$ \\
\hline \multirow{3}{*}{ A } & \multirow{3}{*}{ Flat } & \multirow{3}{*}{ Transverse } & Growth $^{\mathrm{a}}$ & \multirow{3}{*}{$4^{\circ}$} & 1 \\
\hline & & & & & \\
\hline & & & Finishing $^{\mathrm{a}}$ & & 2 \\
\hline \multirow{3}{*}{$\mathrm{B}$} & \multirow{3}{*}{ Flat } & \multirow{3}{*}{ Transverse } & Growth $^{\mathrm{a}}$ & \multirow{3}{*}{$6^{\circ}$} & 1 \\
\hline & & & & & \\
\hline & & & Finishing $^{\mathrm{a}}$ & & 2 \\
\hline
\end{tabular}

${ }^{\mathrm{a}}$ Growth period: $20.61-83.40 \mathrm{~kg}$ live weight; finishing period: $83.40-117.83 \mathrm{~kg}$ live weight.

To determine the percentage of dry matter of solid fraction and liquid fraction (total solids), the samples were oven dried at a temperature of $105^{\circ} \mathrm{C}$ until a constant weight was reached.

Separation and drying efficiency of the excreta (SDEE) was defined as the ratio of dry matter content of the solid fraction to dry matter content of fresh faeces.

To calculate the properties of the air in the rooms and the exhaust air, six sensors HOBO (Hobo Pro v2 U23-001) were used. In each room, one of the sensors was situated center in the room and $1.10 \mathrm{~m}$ high; the other two sensors were $0.40 \mathrm{~m}$ before the fans. These equipment records temperature (operation range: $-40^{\circ} \mathrm{C}$ to $+70^{\circ} \mathrm{C}$; accuracy: $0.2^{\circ} \mathrm{C}$ between $0^{\circ} \mathrm{C}$ and $50^{\circ} \mathrm{C}$; resolution: $0.02^{\circ} \mathrm{C}$ at $25^{\circ} \mathrm{C}$ ) and relative humidity (operation range: $0 \%$ to $100 \%$; accuracy: 
$2.5 \%$ between $10 \%$ and $70 \%$; resolution: $0.03 \%$ ) every two minutes. With those values, humidity ratio of the air in the rooms and the exhaust air were calculated.

\subsection{Statistical Analysis}

The data of variables: dry matter content of the solid fraction and fresh faeces, total solids content of the liquid fraction, average production of solid and liquid fraction, and separation and drying efficiency of the excreta were subjected to analyses of variance by the ANOVA process of the Statgraphics Centurion. The statistical model included the effect of flat belt slope angle.

\section{Results and Discussion}

The effect of the slope angle on the dry matter content and the average production of the solid fraction are shown in Table 3.

The data analysis shows that the slope angle had a significant effect on the percentage of dry matter content (\% DM) of the solid fraction, whether during all fattening cycle $(P<0.0001)$ as for each of the two periods considered (growth period: $P=0.0081$; finishing period: $P<0.0001)$. This indicates the different separation efficiency of faeces and urine on the belt. Separation efficiency is always improved with the greater slope angle of $6^{\circ}$. These results confirm previous observations of [8]. In front of other studies [6], our results for \% DM of the solid fraction show that in situ separation system that we propose separates faeces and urine very efficiently.

Table 3. Effect of slope angle on dry matter content and average production of the solid fraction.

\begin{tabular}{ccccccc}
\hline \multirow{2}{*}{ Slope angle } & \multicolumn{5}{c}{ Periods } \\
\cline { 2 - 7 } & \multicolumn{2}{c}{ Whole fattening } & \multicolumn{2}{c}{ Growth $^{\mathrm{a}}$} & \multicolumn{2}{c}{ Finishing $^{\mathrm{a}}$} \\
\cline { 2 - 7 } & $\mathrm{N}$ & $\% \mathrm{DM}$ & $\mathrm{N}$ & $\% \mathrm{DM}$ & $\mathrm{N}$ & $\% \mathrm{DM}$ \\
\hline $4^{\circ}$ & 39 & 29.91 & 21 & 28.24 & 18 & 31.87 \\
$6^{\circ}$ & 39 & 32.65 & 21 & 31.01 & 18 & 34.57 \\
SEM & & 0.326 & & 0.639 & & 0.291 \\
$P$ & & & & & \\
Slope angle & $\mathrm{N}$ & APSF & $\mathrm{N}$ & APSF & $\mathrm{N}$ & APSF \\
$4^{\circ}$ & 15 & 0.022401 & 8 & 0.025210 & 7 & 0.019185 \\
$6^{\circ}$ & 15 & 0.021391 & 8 & 0.022995 & 7 & 0.019557 \\
SEM & & 0.001308 & & 0.00212 & & 0.000614 \\
$P$ & & 0.5897 & & 0.4733 & & 0.6759 \\
\hline
\end{tabular}

${ }^{\mathrm{a}}$ Growth period: $20.61-83.40 \mathrm{~kg}$ live weight; finishing period: $83.40-117.83 \mathrm{~kg}$ live weight. $\mathrm{N}=$ number of observations. \% DM = dry matter content of the solid fraction (\%). APSF = average production of solid fraction $\left(\mathrm{kg} \cdot \mathrm{kg} \mathrm{LW} \mathrm{LW}^{-1} \mathrm{day}^{-1}\right) . \mathrm{LW}=$ live weight. $\mathrm{SEM}=$ standard error of mean. $P=$ probability values resulting from the analysis of variance. 
The system of [10], with flat belt and a transverse slope angle of $4^{\circ}$ and animal raised from approximately 25 to $55 \mathrm{~kg}$ live weight, was more efficient in the separation of faeces and urine than the flat belt of our experiment with $4^{\circ}$ or $6^{\circ}$. This difference may be due mainly to the times of day used to empty the belts: [10] found that the time of extraction influenced on the DM content of the solid fraction, with highest values around 06.00 hours and the smallest at around 18.00 hours, likely linked to the diurnal urination pattern of the pigs (little urine is produced at night, as the faeces could dry more completely). In our study, belts extractions have been done at 10.00 hours (growth period) and at 10.00 and 19.00 hours (finishing period), unfavourable moment according to [10].

The dry matter content of the solid fraction was higher in the finishing period than in the growth period with both slope angles studied, and the differences of the DM content between periods was similar for the two slope angles considered (3.63\% and $3.56 \%$ for $4^{\circ}$ and $6^{\circ}$, respectively). The possible cause of this difference is a more favourable surface-volume ratio for water evaporation of droppings on the belt with two extractions per day (finishing period) than with one extraction (growth period), because the clusters of solids on the belt were smaller in the finishing period.

In absolute values, the differences among slope angles for dry matter content of solid fraction were slightly higher in growth period than in the finishing period ( 2.77 vs. 2.70 , respectively); however, the differences in relative values between periods for dry matter content of solid fraction were higher for $4^{\circ}$ than for $6^{\circ}(112.85 \%$ vs. $108.47 \%$, respectively), so it may be more advantageous to carry out two extractions per day in the finishing period for $4^{\circ}$ slope angle than for $6^{\circ}$.

The slope angle had no effect on the average production of solid fraction per $\mathrm{kg}$ of live weight and day (APSF) neither at the whole period (growth and finishing periods together) nor at each period separately (growth and finishing) (Table 3). The APSF was lower in the finishing period than in growth period with both slope angles; those results may be explained for the reduction of feed consumption per $\mathrm{kg}$ of live weight and day of the pigs as animals increase their live weight (LW): $29.75 \mathrm{~kg} \cdot \mathrm{LW}: 50.72 \mathrm{~g} \cdot \mathrm{kg} \mathrm{LW}^{-1} \mathrm{day}^{-1} ; 56.16 \mathrm{~kg} \mathrm{LW}: 39.38 \mathrm{~g} \cdot \mathrm{kg} \mathrm{LW}^{-1}$ day $^{-1}$; $88.74 \mathrm{~kg}$ LW: $36.09 \mathrm{~g} \cdot \mathrm{kg} \mathrm{LW}^{-1}$ day $^{-1}$; $111.12 \mathrm{~kg} \mathrm{LW}: 32.19 \mathrm{~g} \cdot \mathrm{kg} \mathrm{LW}^{-1}$ day $^{-1}$.

Always the \% DM of the solid fraction produced was clearly greater than the $\% \mathrm{DM}$ of the fresh faeces collected from the slat. The results of the variance analysis of the dry matter content of the fresh faeces are showing in Table 4. These values are shown as a reference for comparison with the values of the solid fraction from the belt. As expected, no significant differences in dry matter content of the fresh faeces was observed, but in both rooms the dry matter content of the fresh faeces was slightly higher in the finishing period than in the growth period: may be a reflection of the higher average temperature inside the rooms in the finishing period than in the growth period $\left(23.9^{\circ} \mathrm{C}\right.$ vs. $23.6^{\circ} \mathrm{C}$, respectively).

The difference between \% DM of fresh faeces and \% DM of the solid fraction 
Table 4. Dry matter content of the fresh faeces collected from the slatted floor.

\begin{tabular}{ccccccc}
\hline \multirow{2}{*}{ Room } & \multicolumn{5}{c}{ Periods } \\
\cline { 2 - 7 } & \multicolumn{2}{c}{ Whole fattening } & \multicolumn{2}{c}{ Growth $^{\mathrm{a}}$} & \multicolumn{2}{c}{ Finishing $^{\mathrm{a}}$} \\
\cline { 2 - 7 } & $\mathrm{N}$ & $\% \mathrm{DM}$ & $\mathrm{N}$ & $\% \mathrm{DM}$ & $\mathrm{N}$ & $\% \mathrm{DM}$ \\
\hline $\mathrm{A}$ & 39 & 22.76 & 21 & 22.21 & 18 & 23.38 \\
B & 39 & 23.11 & 21 & 22.74 & 18 & 23.54 \\
SEM & & 0.225 & & 0.304 & & 0.166 \\
$P$ & & 0.2004 & & 0.3202 & & 0.5187 \\
\hline
\end{tabular}

âGrowth period: $20.61-83.40 \mathrm{~kg}$ live weight; finishing period: $83.40-117.83 \mathrm{~kg}$ live weight. $\mathrm{N}=$ number of observations. \% DM = dry matter content of the solid fraction (\%). SEM = standard error of mean. $P=$ probability values resulting from the analysis of variance.

indicates a considerable drying of the droppings on the belt. For a particular day, Figure 3 shows humidity ratios of air in the rooms (animal house) and at the exhaust fans after going over the belts: the increase in humidity ratio was due to evaporation of water from droppings accumulated on the belt.

That is, the results of $\% \mathrm{DM}$ of the solid fraction were due to both the separation efficiency of faeces-urine as the drying efficiency of the droppings on the belts.

Separation and drying efficiency were significantly higher for the angle of $6^{\circ}$ than for the $4^{\circ}$ (Table 5), during the whole fattening period and for the growth period and the finishing period separately. For both slope angles $\left(4^{\circ}\right.$ and $\left.6^{\circ}\right)$, this efficiency was higher in the finishing period than in the growth period $\left(6^{\circ}\right.$ : 1.4122 vs. $1.4155 ; 4^{\circ}: 1.2694$ vs. 1.3421 , in growth and finishing period, respectively). However, the increase in separation and drying efficiency when changed from one extraction per day (growth period) to two extractions per day (finishing period) was considerably higher for the slope angle of $4^{\circ}$ than for $6^{\circ}(105.72$ vs. $100.23 \%$, respectively). These results, together with those of the $\%$ DM of solid fraction (Table 3), show that to do two extractions per day in the finishing period is more advantageous for slope angle of $4^{\circ}$ than $6^{\circ}$ : for slope angle of $6^{\circ}$, the separation and drying efficiency was not improved with more than one extraction per day.

The effect of slope angle on average production of liquid fraction (AVLF) and total solids content (TS) of liquid fraction are presented in Table 6. As shown, no differences between slope angles were found, but with $6^{\circ}$ AVLF tend to be greater than with $4^{\circ}$, especially at finishing period: AVLF for $6^{\circ}$ slope angle were $143.22 \%$ of AVLF for $4^{\circ}$ slope angle, meanwhile at growth period were $111.09 \%$. These results shows that the faeces-urine separation at the belt was more efficient with a slope angle of $6^{\circ}$ than with $4^{\circ}$, probably because the higher slope angle made easier the drainage of the urine over the belt.

However, TS was greater with $4^{\circ}$ slope angle than with $6^{\circ}$ (significant difference only for finishing period -two extractions per day, $P=0.0299$ ). This could be explained because of the different dragging of faeces along the belt by the 


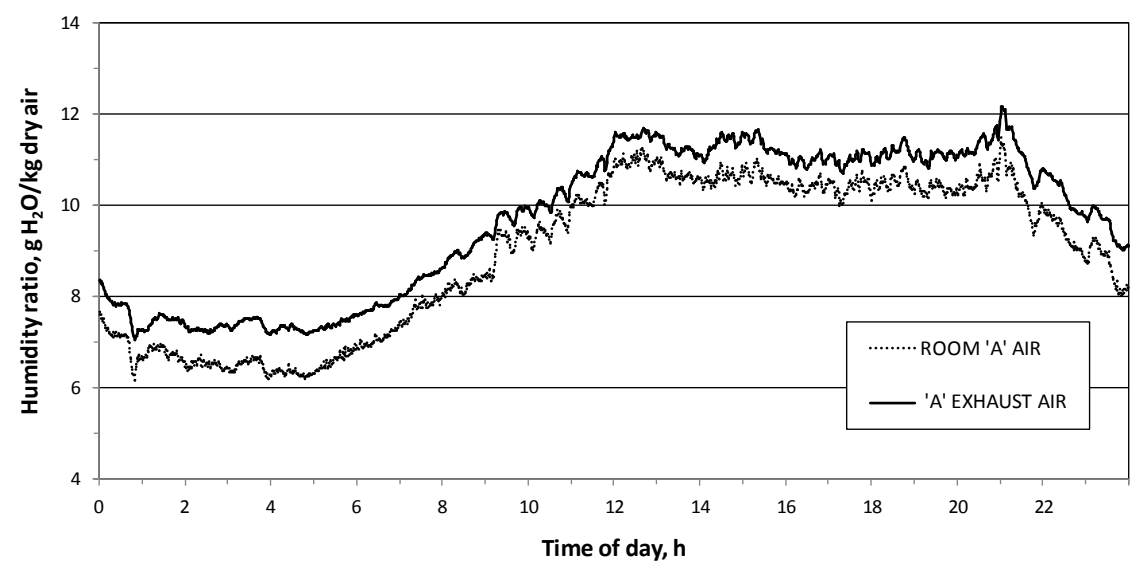

(a)

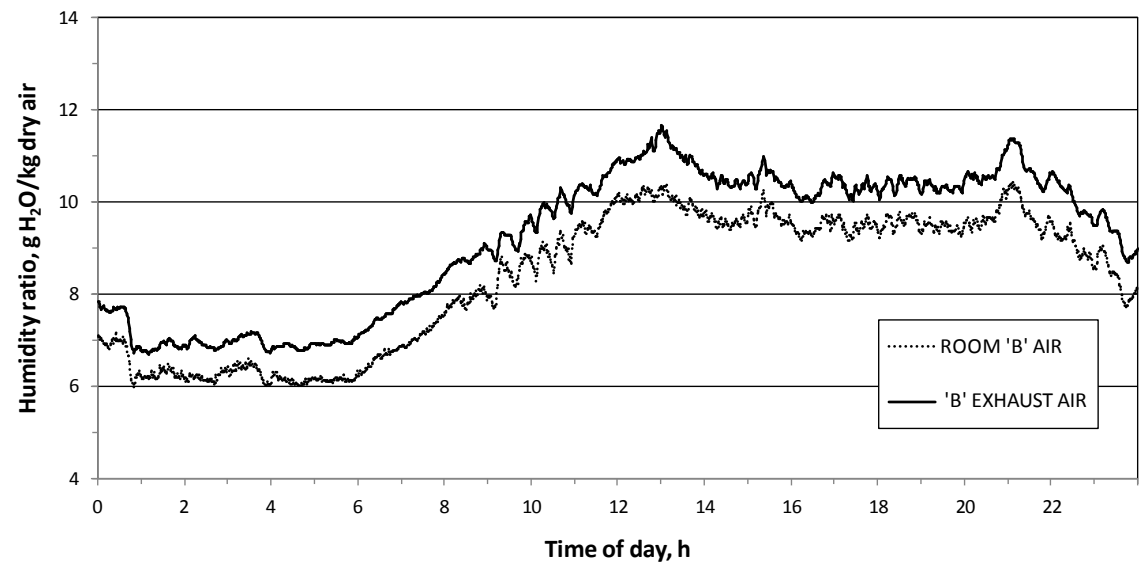

(b)

Figure 3. Humidity ratios in the room and at the exhaust air during a specific day: (a) room A-mean live weight of pigs, $98.66 \mathrm{~kg}$; (b) room B-mean live weight of pigs, 87.45 $\mathrm{kg}$.

Table 5. Effect of slope angle on separation and drying efficiency of the excreta.

\begin{tabular}{cllllll}
\hline \multirow{2}{*}{ Slope angle } & \multicolumn{9}{c}{ Periods $^{2}$} \\
\cline { 2 - 7 } & \multicolumn{2}{l}{ Whole fattening } & \multicolumn{2}{c}{ Growth $^{\mathrm{a}}$} & \multicolumn{2}{c}{ Finishing $^{\mathrm{a}}$} \\
\cline { 2 - 7 } & $\mathrm{N}$ & SDEE & $\mathrm{N}$ & SDEE & $\mathrm{N}$ & SDEE \\
\hline $4^{\circ}$ & 39 & 1.3030 & 21 & 1.2694 & 18 & 1.3421 \\
$6^{\circ}$ & 39 & 1.4137 & 21 & 1.4122 & 18 & 1.4155 \\
SEM & & 0.0123 & & 0.0197 & & 0.0110 \\
$P$ & & 0.0001 & & 0.0106 & & $<0.0001$ \\
\hline
\end{tabular}

${ }^{\mathrm{a}}$ Growth period: $20.61-83.40 \mathrm{~kg}$ live weight; finishing period: $83.40-117.83 \mathrm{~kg}$ live weight. $\mathrm{N}=$ number of observations. SDEE $=$ separation and drying efficiency of the excreta. SEM $=$ standard error of mean. $P=$ probability values resulting from the analysis of variance.

urine, or because of the different rate of water evaporation. The greater calculated production of total residues (solid fraction + liquid fraction) for $6^{\circ}$ slope angle at finishing period (shown in Table 7) seems to point to that rate of water evaporation is the main cause: with two extractions per day, this rate were greater 
Table 6. Effect of slope angle on total solids content and average production of liquid fraction.

\begin{tabular}{ccccccc}
\hline \multirow{2}{*}{ Slope angle } & \multicolumn{6}{c}{ Periods } \\
\cline { 2 - 7 } & \multicolumn{2}{c}{ Whole fattening } & \multicolumn{2}{c}{ Growth $^{\mathrm{a}}$} & \multicolumn{2}{c}{ Finishing $^{\mathrm{a}}$} \\
\cline { 2 - 7 } & $\mathrm{N}$ & AVLF & $\mathrm{N}$ & AVLF & $\mathrm{N}$ & AVLF \\
\hline $4^{\circ}$ & 15 & 0.018662 & 8 & 0.021057 & 7 & 0.015924 \\
$6^{\circ}$ & 15 & 0.023401 & 8 & 0.023392 & 7 & 0.022806 \\
SEM & & 0.002150 & & 0.002386 & & 0.003421 \\
$P$ & & 0.1094 & & 0.4104 & & 0.1805 \\
Slope angle & $\mathrm{N}$ & TS & $\mathrm{N}$ & $\mathrm{TS}$ & $\mathrm{N}$ & $\mathrm{TS}$ \\
$4^{\circ}$ & 39 & $26,075.0$ & 21 & $24,477.5$ & 18 & $27,938.7$ \\
$6^{\circ}$ & 39 & $24,105.2$ & 21 & $23,929.0$ & 18 & $24,310.0$ \\
SEM & & 925.7 & & $1,396.6$ & & $1,131.9$ \\
$P$ & & 0.1366 & & 0.7826 & & 0.0299 \\
\hline
\end{tabular}

${ }^{\mathrm{a}}$ Growth period: $20.61-83.40 \mathrm{~kg}$ live weight; finishing period: $83.40-117.83 \mathrm{~kg}$ live weight. $\mathrm{N}=$ number of observations. AVLF $=$ average production of liquid fraction $\left(\mathrm{L} \cdot \mathrm{kg} \mathrm{LW}^{-1} \mathrm{day}^{-1}\right) . \mathrm{LW}=$ live weight. TS $=$ total solids content of the liquid fraction $\left(\mathrm{mg} \cdot \mathrm{L}^{-1}\right) . \mathrm{SEM}=$ standard error of mean. $P=$ probability values resulting from the analysis of variance.

Table 7. Calculated production of total residues (solid fraction + liquid fraction) $(\mathrm{kg} \cdot \mathrm{kg}$ $\mathrm{LW}^{-1}$ day $\left.^{-1}\right)^{\mathrm{a}}$.

\begin{tabular}{cccc}
\hline \multirow{2}{*}{ Slope angle } & \multicolumn{3}{c}{ Periods } \\
\cline { 2 - 4 } & Whole fattening & Growth $^{\mathrm{b}}$ & Finishing $^{\mathrm{b}}$ \\
\hline $4^{\circ}$ & 0.041287 & 0.046520 & 0.035300 \\
$6^{\circ}$ & 0.045026 & 0.046621 & 0.042591 \\
\hline
\end{tabular}

${ }^{a}$ Calculated values from data of the Table 3 and Table 6. Specific gravity considered of the liquid fraction: $4^{\circ}$ slope angle, $1.012 \mathrm{~kg} \cdot \mathrm{L}^{-1} ; 6^{\circ}$ slope angle, $1.010 \mathrm{~kg} \cdot \mathrm{L}^{-1} .{ }^{\mathrm{b}}$ Growth period: 20.61 - $83.40 \mathrm{~kg}$ live weight; finishing period: 83.40 - $117.83 \mathrm{~kg}$ live weight.

with a $4^{\circ}$ slope angle because of the urine remained more time over the belt than with $6^{\circ}$.

Finally, note that our AVLF results are quite lower than those reported by other authors that use conveyor belts for faeces-urine separation too, probably because of our ventilation system: [5], in two experiments with pigs live weight from 27 to 55 and from 23 to $51 \mathrm{~kg}$, found AVLF values of 0.02382 and 0.04054 $\mathrm{L} \cdot \mathrm{kg} \mathrm{LW}^{-1}$ day $^{-1}$, respectively; [2] in three experiments with pigs live weight from 26.14 to 113.25 , from 26.66 to 113.25 and from 24.77 to $117.68 \mathrm{~kg}$, obtained AVLF values of $0.04182,0.03890$ and $0.05101 \mathrm{~L} \cdot \mathrm{kg} \mathrm{LW}^{-1} \mathrm{day}^{-1}$, respectively; and [11], in two experiments with pigs live weight from 24.7 to 102.3 and from 25.6 to $110.3 \mathrm{~kg}$, found AVLF values of 0.03417 and $0.02825 \mathrm{~kg} \cdot \mathrm{kg} \mathrm{LW}^{-1}$ day $^{-1}$, respectively.

\section{Conclusions}

The flat belts are an appropriate system to separate faeces and urine properly 
and to dry the remaining faeces with the important help of the exhaust ventilation system underneath slatted floor. A transverse slope angle of $6^{\circ}$ makes possible to obtain higher values of dry matter content in the solid fraction than a transverse slope angle of $4^{\circ}$. To increase the $\% \mathrm{DM}$ of the solid fraction, with a slope angle of $6^{\circ}$, only one extraction per day is enough along the whole fattening period, but with $4^{\circ}$, the efficiency of the system is increased in the finishing period with two extractions per day.

\section{Acknowledgements}

This project was financed by TRAGSA; the authors would like to thank this Public Spanish Company.

\section{References}

[1] Daudén, A., Quílez, D. and Vera, M.V. (2004) Pig Slurry Application and Irrigation Effects on Nitrate Leaching in Mediterranean Soil Lysimeters. Journal of Environmental Quality, 33, 2290-2295. https://doi.org/10.2134/jeq2004.2290

[2] Baird, C., Humenik, M., Rice, M., Classen, J., Liehr, S., Zering, K. and Van Heugten, E. (2004) Belt System for Manure Removal. Project Report for North Carolina Attorney General Agreement Initiative, Animal and Poultry Waste Management Center North Carolina State University, Raleigh, NC.

[3] Ogink, N.W.M., Willers, H.C., Aarnink, A.J.A. and Satter, I.H.G. (2000) Development of a New Pig Production System with Integrated Solutions for Emission Control, Manure Treatment and Animal Welfare Demands. Swine Housing First International Conference ASAE, Des Moines, IA, 253-259.

[4] Vázquez, J., Garcimartín, M.A., Ovejero, I. and Daza, A. (2001) A New Integral System for Waste Management in Pig Housing, Based on a Special and Adjustable Floor Belt under Partial Slat, to Avoid Slurry Production. Sixth International Livestock Environment Symposium, Louisville, KY.

[5] Van Kempen, T., Kaspers, B., Burnette, P., Van Kempen, M. and Koger, J.B. (2003) Swine Housing with a Belt for Separating Urine and Faeces; Key to Flexibility. Swine Housing II. Proceedings of Conference Research Triangle, Park, NC, 159-165.

[6] Lachance, I., Godbout, S., Marquis, A., Larouche, J.P. and Pouliot, F. (2005) Separation of Pig Manure under Slats: to Reduce Releases in the Environment. ASABE Annual International Meeting, Tampa, FL, 17-20 July 2005, Article No. 054159. https://doi.org/10.13031/2013.19914

[7] Alonso, F., Vázquez, J., Sánchez, E., Ovejero, I., Mateos, A. and Garcimartín, M.A. (2008) Comparison of Dry Matter Content of Pig Faeces in Two Belt Separation Systems. Proceedings of VIII International Livestock Environment Symposium, ASABE S ILES VIII, Iguassu Falls City, 1059-1062.

[8] Alonso, F., Vázquez, J., Ovejero, I., Garcimartín, M.A., Mateos, A. and Sánchez, E. (2010) Belt Separation System under Slat in Fattening Pig Housing: Effect of Belt Type and Extraction Frequency. Bioresource Technology, 101, 6230-6234. https://doi.org/10.1016/j.biortech.2010.02.106

[9] Ovejero, I., Daza, A., Garcimartín, M.A. and Vázquez, J. (2004) Design of an Experimental Fattening Pig Housing: Part I, Climatic Control. International Symposium of the International Commission of Agricultural Engineering (CIGR), Evora, 
2-6 May 2004.

[10] Koger, J.B., O’Brien, B.K., Burnette, R.P., Kai, P., Van Kempen, M.H.J.G., Van Heugten, E. and Van Kempen, T.A.T.G. (2014) Manure Belts for Harvesting Urine and Faeces Separately and Improving Air Quality in Swine Facilities. Livestock Science, 162, 214-222. https://doi.org/10.1016/j.livsci.2014.01.013

[11] Aarnink, A.J.A. and Ogink, N.W.M. (2007) Environmental Impact of Daily Removal of Pig Manure with a Conveyer Belt System. International Symposium on Air Quality and Waste Management for Agriculture, Broomfield, CO, 16-19 September 2007. 